\title{
NILAI-NILAI PENDIDIKAN ISLAM DALAM BUKU “ORANG MAIYAH” KARYA EMHA AINUN NADJIB
}

\author{
Wardatul Ummah
}

Institut Agama Islam Riyadlotul Mujahidin Ngabar Ponorogo

\begin{abstract}
Today's education can be said to be alarming, as a person who is concerned in education we must not be trapped in material things, for example we judge the level of education of a person from the degree he has, how many degrees he has and where he got it, but today we do not see a more substantial state of "They". Let's look at school children at this time have reduced respect for older people and think more biased and smarter than others. In the context of learning, doctrination still occurs in each subject matter. Learning activities are more focused on the minimum level of thinking (low order thinking), the teacher's job is simply to at the same time prohibit students - without providing opportunities for independent learning. This kind of educational practice by Emha Ainun Nadjib is often criticized that schools are like factories that require product standardization.
\end{abstract}

Keywords: Education, Maiyyah

\section{A. Latar Belakang}

Pendidikan hari ini bisa dikatakan memprihatinkan, sebagai seorang yang konsen dalam pendidikan kita tidak boleh terjebak pada hal-hal yang bersifat material, misalnya kita menilai tingkat pendidikan seseorang dari gelar yang ia punya, berapa gelar yang ia punya dan dari mana saja ia mendapatkanya, tapi hari ini kita tidak melihat keadaan yang lebih substansional dari "Mereka". Mari kita lihat anak-anak sekolah saat ini sudah berkurang sikap hormat terhadap yang lebih tua dan beranggapan lebih bias dan pintar dari orang lain.

Ketertinggalan sebuah bangsa dari bangsa lain sesungguhnya disebabkan oleh ketidakmampuan pendidikan menjawab tantangan zaman. Ketidakmampuan ini disebabkan oleh kegagalan pendidikan meletakkan pondasi yang kuat bagi pengembangan ilmu pengetahuan. Bahkan pendidikan saat ini terkesan gamang antara memelihara tradisi atau mengejar modernisme. Selain itu, pendidikan belum memiliki kebulatan dalam memadukan antara ilmu dan agama. Pada saat bersamaan, terjadi perubahan 'besar-besaran' yang terjadi dalam masyarakat bahkan dunia. Globalisasi meniscayakan untuk setiap individu, kelompok, bahkan agama, berpikir ulang (rethinking) terhadap eksistensinya di muka bumi ini.

Secara normatif, sebuah lembaga pendidikan didirikan dengan maksud turut serta mencerdaskan kehidupan berbangsa. Namun, pada sejarah dan praktiknya kini, 
tatkala iklim kompetisi dihembuskan dan diketahui bahwa ternyata pendidikan menggiurkan pula sebagai lahan bisnis, visi normatif itu bisa saja tinggal kata-kata saja. Bahkan mungkin saja banyak yang sudah lupa. Carilah sendiri atmosfernya di dunia pendidikan kita dalam dua puluh tahun terakhir ini. Dalam berbudaya, yang harus ditumbuhkan adalah budi pekerti. Jika anak tumbuh dengan budi pekerti yang baik, maka hingga dewasa terbentuklah sikap-sikap yang sesuai norma dan nilai dalam agama dan budi pekertinya juga terbentuk dengan baik.

Dalam konteks bangsa Indonesia, pendidikan tidak bisa lepas dari sistem pendidikan nasional. Artinya setiap kebijakan yang dikeluarkan oleh pemerintah pasti akan membawa dampak pada satuan pendidikan, baik lembaga formal maupun informal. Selain itu, pendidikan secara makro, masih terjebak pada problem kuantitatif yang itu sebetulnya kurang menguntungkan dari segi mutu pendidikan. Ada sebuah kebiasaan, pergantian pejabat, khususnya menteri pendidikan, maka hampir bisa dipastikan akan adanya perubahan kebijakan (policy) yang terkait dengan penyelenggaraan pendidikan.

\section{B. Pembahasan}

1. Biografi Emha Ainun Nadjib

Emha adalah anak desa. Tepatnya desa santri. Pada rabu legi, $27 \mathrm{Mei}$ 1953, Emha Lahir di Menturo, Sumobito, Jombang, Jawa Timur. Menturo sebagai kandang budaya tradisi merupakan bagian penting dari pengambaran panjang Emha, baik secara sosial, intelektual, kultur, maupun spiritual.

Emha merasa bersyukur sebagai anak desa. Dari desa ia mendapatkan berbagai pengalaman dan pelajaran tentang kesederhanaan, keprasajaan, kewajaran, dan kearifan hidup. "Saya belajar banyak dari orang desa 'berhati petani'. Mereka hanya makan yang ditanam. Mereka menuai hasil berdasarkan kewajaran bekerja. Mereka menjadikan kerja sebagai orientasi hidup. Mereka tak pernah menguasai, mengeksploitasi alam dan sesama manusia. Mereka tabah, meskipun ditindih penderitaan. Saya benar-benar cemburu pada kualitas hidup mereka," tuturnya.

Karena pelajaran besar itulah, Emha menganggap peran sosial bukan sebagai karier, melainkan sebagai kewajiban kerja dan fungsi sosial yang mampu memberi makna kepada masyarakat. Makna itu bisa berwujud sikap pemihakan terhadap yang lemah atau dilemahkan. Atau, bisa juga upaya mencari berbagai kemungkinan nilai "ideal" atau moral di tengah kebangkrutan budaya 
masyarakat. Apa pun hasilnya, hanyalah sebagai akibat belaka. "Salah satu kebahagiaan hidup saya adalah bekerja..," katanya.

Karena pelajaran besar dari desa itu pula, Emha tetap "bertahan" untuk hidup sederhana. Dikatakan sederhana karena secara ekonomis ia sesungguhnya mampu "menyesuaikan" diri dengan gaya hidup kelas menengah yang borjuis. Setiap hari ia masih makan di warung pinggir jalan. Sampai-sampai ia sakit karena kurang gizi.

"Aneh, seorang budayawan terkenal mengidap jenis 'penyakit' kelas bawah. Bagaimana mungkin? Bukankah Emha kini sudah berjaya?" ujar seorang kawanya.

“dimanakah kekayaan Emha?” ujar kawanya yang lain. Mungkin orang tidak percaya jika selama ini Emha hanya berfungsi sebagai "selang" atau "talang" dari rezeki yang diterimanya. Rezeki itu dikembalikan kepada masyarakat untuk membiayai fungsi-fungsi sosial. Ia ikut menangani Yayasan Pembangunan Masyarakat "Al-Muhammady" di Jombang yang bergerak di bidang pendidikan, sosial-ekonomi, dan sosial budaya. Ia pun ikut kiprah dalam Yayasan "Ababil" di Yogyakarta yang menyediakan tenaga advokasi pengembangan masyarkat. Selain itu, secara ekonomis dan kasuistik, Emha masih harus terlibat dengan orang-orang atau pihak-pihak yang membutuhkan bantuan.

Emha memandang kehidupan sosialnya sebagai hal yang wajar dalam kehidupan yang dibebani kewajiban untuk bekerja; bekerja secara fungsional yang berarti bagi rakyat, bukan sebagai karier. Makna ini, menurut Emha, dapat mengambil bentuk sebagai pemihakan pada si lemah dan orang-orang yang dilemahkan oleh rekayasa sesama mereka.

Dalam hal menulis, Cak Nun berprinsip menulis bukanlah untuk menempuh karier sebagai penulis, melainkan untuk keperluan-keperluan sosial. Dengan prinsip itu Cak Nun justru telah menghasilkan sangat banyak tulisan, mulai dari puisi, esai, artikel, naskah drama, cerpen, makalah hingga buku. Pendidikan formal Emha berakhir pada semester satu pada Fakultas Ekonomi Universitas Gadjah Mada Yogyakarta. Sebelumnya Emha pernah dikeluarkan dari Pondok Modern Gontor Ponorogo, Jawa Timur sebelah selatan Madiun di tahun ketiga masa belajarnya karena memimpin demonstrasi melawan satpam sekolah. Kemudian ia pindah ke Yogyakarta tempat ia menamatkan SMA 
Muhammadiyah. Menarik untuk dicatat, walaupun Emha dilahirkan dalam lingkungan NU, ia menamatkan pelajaranya di Muhammadiyah. Sudah cukup banyak ditulis orang mengenai pengaruh NU dan Muhammadiyah ${ }^{1}$.

Setelah lulus SMA ia mencoba mencicipi kuliah di Fakultas Ekonomi UGM, tetapi ia tak betah. Ia lebih memilih "kuliah" di "Universitas Malioboro". Bergabung dengan kelompok penulis muda, Persada Studi Klub (PSK), di bawah "maha guru" Umbu Landu Paringgi. Di (PSK) ini Emha makin menyadari potensi kepenyairan dan kepenulisanya. Tulisan-tulisanya tersebar di berbagai media massa. Inilah titik penting dari hadirnya pengakuan masyarakat atas eksistensinya.

Kegelisahan untuk menyodorkan altenatif nilai, membuat Emha selalu "gerah" berada dalam kemampuan institusi. Ia bagaikan udara yang terus beredar, singgah ke ruang untuk kemudian ditinggalkanya. Ia pernah jadi redaktur harian Masa Kini. Ia pernah menjadi sekretaris Dewan kesenian Yogyakarta, tetapi karena kemapanan itu dirasakan menjepit "sayap-sayap kebebasanya”, Emha pun lepas, "memberontak". Yang terakhir, ketika ditunjuk jadi Fungsionaris Ikatan Cendekiawan Muslim Indonesia (ICMI), lagi-lagi Emha "memberontak".

Emha Mulai berkarya melalui multip-media seni Yogyakarta bersamasama dengan sesama aktivis, Halim HD. Ia bekerja dengan sanggarbambu, aktif di Teater Dinasti dan menghasilkan serta mementaskan repetoir yang cukup banyak. Lakon-lakon ini mencakup Geger Wong Ngoyak Macan (1989, karikatur pentas mengenai pemerintahan Raja Soeharto), patung kekasih (1989, mengenai maraknya kultus individu), kerajaan Lik Par ( 1980, mengenai eksploitasi terhadap rakyat oleh berbagai lembaga modern) dan mas Dukun (1982, mengenai kegagalan lembaga-lembaga kepemimpinan modern).

Kemudian dengan kelompok teater Salahuddin, ia menghasilkan santrisantri Khidir, 1990 , yang dipentaskan di lapangan Pesantren Modern Gontor Ponorogo dengan mengikutsertakan semua santri dan penonton yang berjumlah sekitar 35,000. Sekali lagi di tahun 1990 ia menghasilkan Lautan Jilbab yang banyak dipentaskan di Yogyakarta, Surabaya, Makassar. Lakon ini merupakan salah satu karyanya yang paling terkenal, dan kalau kita mencarai data tentang

1 Bahtiar Fahmi Utomo, 2014. Pemikiran Emha Ainun Nadjib tentang pendidikan Islam. PAI. Fakultas Ilmu Tarbiyah dan Keguruan Universitas Islam Negeri Syarif Hidayatulloh Jakarta, Hal 44 
Emha melalui internet mungkin sekali kita akan mendapatkan jawaban dengan referensi mengenai karya ini lebih banyak daripada karya-karya lainya.

Bagai udara, Emha terus beredar, singgah di berbagai ruang dan peristiwa, di Filiphina untuk mengikuti lokakarya teater (1980); International Writing Program di Universitas Iowa Amerika Serikat (1984); Festival Penyair Internasional (1984) di Rotterdam Belanda (1984); dan Festival Horizonte III di Berlin Barat, Jerman $(1985)^{2}$

Bersama Kiai Kanjeng, terhitung dari tahun ke-6 berdirinya (juni 1998), hinga 18 Oktober 2019 cak tun telah mengunjungi $4126^{3}$ titik daerah di pelosok Indonesia, dan juga diundang ke berbagai belahan dunia, diantaranya, tur 6 kota di Mesir, tur di Malaysia dan rangkaian tur di Eropa; Inggris, Jerman, Skotlandia dan Italia, dan hingga saat ini masih aktif dengan kegiatan sinau bareng bersama Maiyah, beberapa jadwal rutin yang dilakukan Cak Nun antara lain; Padhangmbulan Jombang berlangsung setiap tanggal 15 bulan Jawa atau tepat pada saat malam bulan purnama. Mocopat Syafaat Yogyakarta setiap tanggal 17. Kenduri Cinta Jakarta setiap hari Jumat minggu kedua. Gambang Syafaat Semarang setiap tanggal 25. Bangbang Wetan Surabaya berlangsung sehari setelah Padhangmbulan. Di luar jadwal di atas, Maiyahan Rutin juga berlangsung di beberapa kota seperti di Makassar, Magelang, Purwokerto, Madiun, Malang, Lampung, Bandung, Pekalongan, Pemalang, Blitar, Wonosobo dll yang berlangsung secara rutin maupun tentatif. Jadwal bisa dilihat melalui akun-akun Lingkar Maiyah.

2. Pokok-Pokok Pikiran Emha Ainun Nadjib dalam Buku "Orang Maiyah"

Emha dalam buku "Orang Maiyah" ini berperan sebagai polisi lalu lintas dari orang-orang atau jemaah maiyah yang menulis surat kepada Emha.(Emha Ainun Nadjib 2016; Orang Maiyah, Bentang Pustaka Yogyakarta, hal 1) jadi Emha disini mencoba untuk memposisikan dirinya dan jamaah maiyah lainya setara, karena dalam maiyah sendiri tidak mengenal konsep guru dan murid. Semua orang mempunyai kesempatan yang sama untuk bisa menjadi seorang guru juga sekaligus menjadi seorang murid. Emha tidak ingin banyak jamaah berangapan bahwa dirinya adalah orang suci yang ingin mencerahkan dunia.

\footnotetext{
${ }^{2}$ Emha Ainun Nadjid, Tuhan pun cemburu, Bentang Pustaka;2015, hal 440-442

${ }^{3}$ Diambil dari akun Youtube.com/CakNun.com tanggal 1 November 2019
} 
Emha ingin buah pikiranya tertransfer kepada orang-orang maiyah lainya, yang kemudian melanjutkan lagi kepada orang-orang disekitar mereka.

Emha Ainun Nadjib memiliki media tersendiri untuk menyampaikan ilmu dan berdiskusi tentang masalah yang marak sekarang. Media yang digunakan ialah komunitas atau jemaah maiyah. Sebutan jamaah atau jemaah ini tidak benar-benar bergerak secara institutif sebagai kelompok eksklusif tertentu. Jemaah ini secara rutin berkumpul dalam forum bersama Cak Nun. Acara ini mungkin bisa dibilang pengajian, tapi standar yang biasa ditemui dalam sebuah acara pengajian tidak benar-benar menjadi dominan. Sebab di dalamnya lebih banyak mengajarkan semangat hidup, sikap toleran dan hidup bersama dalam kontribusi kebaikan. Jadi boleh juga dibilang bahwa jemaah maiyah tidaklah identik sebagai sekumpulan orang Islam saja, malah seringkali hadir dalam pengajian ini tokoh-tokoh lintas Agama, Aliran, Suku Bangsa, Etnik, LSM, Mahasiswa dalam dan luar negeri. Nuasanya sangat berbudaya dan tidak juga serta-merta menjadi sinkretisme(Bahtiar Fahmi Utomo, 2014. Pemikiran Emha Ainun Nadjib tentang pendidikan Islam. PAI. Fakultas Ilmu Tarbiyah dan Keguruan Universitas Islam Negeri Syarif Hidayatulloh Jakarta, Hal 51) atau suatu proses perpaduan dari beberapa paham-paham atau aliran-aliran agama atau kepercayaan. Pada sinkretisme terjadi proses pencampuradukkan berbagai unsur aliran atau paham, sehingga hasil yang didapat dalam bentuk abstrak yang berbeda untuk mencari keserasian, keseimbangan ${ }^{4}$.

Maka pokok-pokok pikiran yang penulis tangkap dalam buku "Orang Maiyah" antara lain sebagai berikut:

Pertama Emha menjelaskan bahwa setiap orang mempunyai kesempatan yang sama untuk menjadi guru dan juga murid

Kedua Emha tidak ingin jamaah menjadikan dirinya sebagai orang yang paling berpengaruh dalam lingkat maiyah

Ketiga Emha menjelaskan bahwa hidup orang Maiyah tidak tergantung kekayaan dan atau kemiskinan, tetapi tergantung pada proses pembelajaran menggunakan akal dan nuraninya untuk menyutradarai hidup menuju yang pantas dituju

\footnotetext{
${ }^{4}$ https://id.wikipedia.org/wiki/Sinkretisme
} 
Keempat Emha ingin jammah maiyah selalu belajar pada hal-hal kecil dan sederhana dalam hidup mereka.

3. Nilai-Nilai Pendidikan Islam dari Buku "Orang Maiyah"

Sebelum kita masuk ke dalam buku "Orang Maiyah" , mari kita kaji kembali, apa itu definisi pendidikan Islam? Dan kita hubungkan arti dari pendidikan itu sendiri kedalam buku "Orang Maiyah", karena dalam hal ini Emha bukan sebagai penulis, hanya sebagai polisi lalu lintas antara buah pemikirian jamaah maiyah itu sendiri.

Dari berbagai terma yang digunakan untuk menunjuk makna pendidikan Islam, Konferensi Internasional Pendidikan Tahun 1977, merekomendasikan bahwa pendidikan Islam ialah keseluruhan pengertian yang terkandung dalam makna tarbiyah, ta 'lim dan ta'dib. Pada konteks ini, dapat diajukan beberapa definisi pendidikan Islam, di antaranya sebagaimana diungkapkan oleh Ahmad D. Marimba yang mengartikan pendidikan Islam sebagai bimbingan jasmani dan Rohani berdasarkan hukum-hukum agama Islam menuju terbentuknya kepribadian utama ialah kepribadian Muslim, yaitu kepribadian yang sesuai dengan nilai-nilai Islam ${ }^{5}$.

Materi yang disampaikan Emha Ainun Nadjib dalam bukunya "Orang Maiyah" ialah beberapa hal tentang pendidikan Islam yaitu pertama tauhid, kedua akhlak (uswatun hasanah), ketiga penyucian Rohani. Adapun penjelasannya sebagai berikut:

1. Tauhid

Dalam buku tersebut kita ambil contoh dalam bagian keikhlasan Induk Ayam, bagian tersebut ditulis oleh salah satu jamah maiyah yang bernama Isman, menjelaskan bahwa semua kejadian di dunia ini tidak bisa lepas dari peran Allah yang Maha Esa, dia mengambil perumpamaan seekor ayam betina, ketika ayam betina tersebut bertelur maka ayam jantan yang membuahinya tidak akan pernah muncul lagi, berbeda jika itu ikan Arwana, ketika si betina bertelur maka yang bertugas menjaga telur adalah arwana jantanm dengan memasukanya ke mulutnya. Apa yang terjadi dengan ayam betina? Dia rela mengerami telurnya hingga menetas sementara ayam jantan yang lain sudah mendapat betina lain untuk dibuahi, karena si ayam betina

\footnotetext{
${ }^{5}$ Mahmud; Pemikiran Pendidikan Islam, Pustaka setia 2011 hal. 24
} 
yakin akan apa yang sudah disyariaatkan kepada ayam jantan, dan dia tetap ikhlas melakukan tugasnya sebagai ibu dari ayam-ayam kecil tanpa ayah.

Salah satu contoh kisah yang berisi nilai tauhid dari kisah seekor ayam, bahwa didalam hal yang remeh temeh pun Allah berada dialamnya, satu lagi kisah yang terkandung di dalam buku tersebut sebatang rokok kretek patah, kita belajar dari sebatang rokok kretek yang patah, kebanyakan orang ketika mendapati kreteknya patah ia lantas akan membuangya, karena kita berfikir sudah tidak bisa diandalkan lagi, sudah tidak bisa digunakan lagi, itu hanya akan terjadi kepada orang-orang yang kehilangan semangat atau putus asa. Dalam buku tersebut dikatakan:

"nak, sudahlah, percayalah tidak akan pernah terlintas untuk membuatumu menderita, apalagi membuatmu menjadi terlantar. Dan yakinlah, jangan pernah engkau terjebak hanya karena kekerdilan pikiran menjadikanmu tidak dewasa. Luaskan dan panjangkanlah perjalananmu. Karena kelak ia akan menjadi salah satu dari 'pupuk', yang membuat lunak dan suburnya lahan tempat engkau bekerja, menjadikan luasnya cakrawala pengetahuanmu yang menjadikanmu untuk tidak terburu-buru dan berputus $a s a^{6}$.

Dalam bagian Akal adalah sayap burung, ditulis oleh seorang maiyah yang bernama Agus, Agus mencoba menganalisi bahwa tugas ibadah manusia tidak berat. Ini karena intinya manusia hanya mengunakan fungsi-fungsi yang sudah dimiliki untuk dioptimalkan menjadi konstruksi positif yang berguna bagi dirinya sendiri dan secara sosial. Ada korelasi di dalam tulisan lompatlompat ini antara burung yang mengepakan sayapnya, akal, ibadah, Nabi Ibrahim dan Nabi Muhammad, Al-Quran, Kekhalifahan dan manusia modern.

Orang maiyah adalah filsuf semua. Itu bukan karena hebat atau soal pinter, filsuf karena orang maiyah sangat serius menjalani hidupnya. Serius menjalani tanggung jawab secara nilai terhadap apa saja yang ia alami, terhadap setiap kata yang ia ucapkan, terhadap setiap keputusan yang ia ambil, maka dari itu ia harus berfilsafat atas setiap zarah dari unsur kehidupan yang sedang ia alami atau dikelolanya.

\footnotetext{
${ }^{6}$ Emha Ainun Nadjib;( orang maiyah, bentang pustaka 2015), hal 39
} 
2. Akhlak

Ketika kita berbicara tentang Akhlak, bagaimana keadaan moral bangsa Indonesia saat ini?: apakah sudah sesuai atau paling tidak perilaku masyarkat tidak dibenci oleh sang Khalik. Akhlak secara terminologi berarti tingkah laku seseorang yang didorong oleh suatu keinginan secara sadar untuk melakukan suatu perbuatan yang baik. Akhlak merupakan bentuk jamak dari kata khuluk, berasal dari bahasa Arab yang berarti perangai, tingkah laku, atau tabiat ${ }^{7}$.

Dalam bagian negeri maiyah kita dapat mengambil pelajaran bahwa orang maiyah memperteguh posisi persaudaraan mereka dunia dan akhirat, bertekad tolong-menolong satu sama lain. Bukan karena negara dan pemerintah tidak bisa menolong rakyat kecil.

Kita tidak boleh menuhankan materialisme, dan berperilaku hedonisme. Betapa besarnya manusia, betapa kecilnya kehidupan disana dijelaskan perubahan sikap mendasar dalam evolusi manusia. Anak kecil sangat cepat menjadi remaja, umur sebelas tahun bisa mengalami menstruasi dan alam pikiran budayanya sudah remaja. Sementara yang remaja sangat sangat lama untuk berkembang menjadi dewasa. Bahkan bisa terjadi orang berumur lima puluh tahun mentalnya masih remaja, cara berfikrinya masih ABG, perilaku dan pertimbangan hidupnya tidak mencerminkan kedewasaan. Mungkin sekali sampai kelak menjadi wafat umur tujuh puluhan tahun, seseorang tidak pernah mengalami menjadi dewasa. Ia tua tetapi ABG.

Satu bagian lagi dalam buku "Orang Maiyah" yang berjudul sarjana sekolahan dan sarjana kehidupan, sekali lagi Emha mengajak kita untuk berfikir luas dan mendalam. Di zaman materialisme ini kita banyak menganggap orang-orang desa yang tidak pernah secara sempurna mendapatkan pendidikan secara formal kita acuhkan, kita anggap tidak terpelajar. Sekali lagi kedewasaan seseorang tidak ditandai oleh tingkat pendidikan formalnya. Kedewasaan tidak pasti berkaitan dengan tingginya jabatan, kesalehan keagamaan seseorang tidak mesti berhubungan dengan banyak ayat Allah yang ia hafal.

3. Penycuian Rohani

\footnotetext{
${ }^{7}$ https://id.wikipedia.org/wiki/Akhlak
} 
Ketika kita sampai pada bagian penyucian rohani, sungguh semua yang ada dalam buku "Orang Maiyah" bisa menjadi alat pemantul atau bahkan cermin untuk melihat hidup kita sendiri. Banyak hal-hal yang barangkali kita sepelekan seperti batang rokok yang patah, seekor ayam betina yang mengerami telurnya dan sebagainya. Bisa jadi karena kita mulai terpapar virus materialisme, kita lebih mempedulikan orang yang mempunyai tingkat pendidikan tinggi, mempunyai kekuasaan, jabatan yang tinggi, itu semua hanya bersifat sementara, dan bukan jaminan atas kebahagiaan. Maka kita harus lebih peka terhadap peristiwa apa saja yang terjadi di hidup kita, keluarga kita, lingkungan kita, dan kita ambil pendidikan seluas-luasnya dari hal-hal remeh temeh sekalipun.

\section{Penutup}

Emha ingin menjelaskan ke masyarakat bahwa sumber kemajuan suatu Negara bisa dilihat dari pendidikanya. Emha menemukan jamaah maiyah yang mempunyai formula untuk mengatasi "busung" tersebut. Sekali lagi bahwa di dalam maiyah tidak mengenal guru dan murid. Bahkan peristiwa sepele dan remeh temeh bila dikaji dan ditelaah lebih mendalam kita akan mendapati pelajaran berharga. semua kisah yang di tulis oleh jamaah maiyah merupakan pengalaman spiritual yang mereka alami, yang mereka ambil pelajaran. Tentang Allah sebagai satu-satunya yang mereka harapkan, dan hanya kepada-Nya mereka bersabar atas apa yang mereka lalui.

Corak pendidikan dalam sistem persekolahan seperti sekarang ini lamakelamaan menampakkan diri sebagai wajah pendidikan yang kering dari kreatifitas dan inovasi yang memperlihatkan gejala mayor hanya menghasilkan "generasi tukang", bukan inovator atau kreator. "Karena untuk berinovasi itu membutuhkan keberanian sedangkan kebiasaan umum yang terjadi sekarang, dunia pendidikan justru menyebabkan peserta didik menjadi takut salah. Esensi pendidikan adalah mempersiapkan peserta didik agar siap menghadapi masa depan yang tidak/belum mereka perhitungkan serta menumbuhkan kemampuan mereka untuk beradaptasi terhadap berbagai kemungkinan yang akan mereka temui dimasa mendatang. Bahwa guru terbaik adalah pengalaman, sedangkan harta yang paling berharga yaitu ilmu. Kemudian bahwa pengalaman itu tidak berarti harus selalu yang bersifat susah/sulit tetapi hal-hal sederhana yang kita temukan sehari-hari bisa jadi belum sungguhsungguh kita fahami kalau benar-benar kita teliti dan cermati. 


\section{Daftar Pustaka :}

Fahmi Utomo, Bahtiar, Pemikiran Emha Ainun Nadjib tentang pendidikan Islam. (PAI.

Fakultas Ilmu Tarbiyah dan Keguruan Universitas Islam Negeri Syarif Hidayatulloh Jakarta,2014)

Nadjid Emha Ainun, Tuhan pun cemburu, (Bentang Pustaka;2015)

Mahmud; Pemikiran Pendidikan Islam, (Pustaka setia 2011 )

Nadjib, Emha Ainun, orang maiyah (bentang pustaka 2015) 